This is an electronic reprint of the original article. This reprint may differ from the original in pagination and typographic detail.

Author(s): Kotiaho, Janne Sakari; Halme, Panu

Title: $\quad$ Aggregating protected habitats embraces implicit habitat conservation triage

Year: $\quad 2014$

Version:

Please cite the original version:

Kotiaho, J. S., \& Halme, P. (2014). Aggregating protected habitats embraces implicit habitat conservation triage. Proceedings of Peerage of Science, 2014(January), Article e5. https://doi.org/10.14726/procpos.2014.e5

All material supplied via JYX is protected by copyright and other intellectual property rights, and duplication or sale of all or part of any of the repository collections is not permitted, except that material may be duplicated by you for your research use or educational purposes in electronic or print form. You must obtain permission for any other use. Electronic or print copies may not be offered, whether for sale or otherwise to anyone who is not an authorised user. 


\title{
Aggregating protected habitats embraces implicit habitat conservation triage
}

\author{
Janne S. Kotiaho $^{\square}$ \& Panu Halme ${ }^{1}$
}

\author{
${ }^{1}$ Department of Biological and Environmental Science, P.O. Box 35, 40014 University of \\ Jyväskylä. Finland. \\ ⿶janne.kotiaho@jyu.fi \\ $\square$ panu.halme@jyu.fi
}

Citation: Kotiaho J \& Halme P (2014) Aggregating protected habitats embraces implicit habitat conservation triage. ProcPoS 1:e5 DOI: $10.14726 /$ procpos.2014.e5

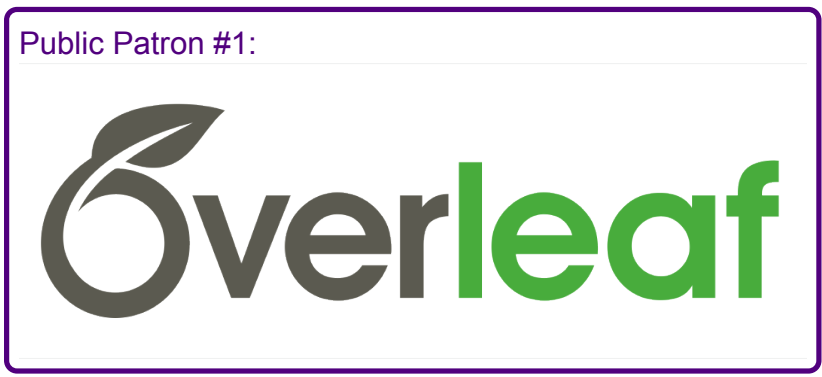

Species-area relationship is one of the most fundamental empirical generalizations in ecology (Rosenzweig 1995; Lomolino 2000), and, although occasionally challenged (e.g. He \& Hubbell 2011), it plays an important role in conservation science owing to its ability to provide approximate assessment of extinctions due to habitat loss (Hanski 2005). In reality, habitat loss is nearly exclusively accompanied with a degree of habitat fragmentation, and despite the acknowledged importance of fragmentation on the risk of extinction (Fahrig 2003), it is remarkable that none of the various formalizations of the species area relationship has taken the relative roles of habitat loss and fragmentation explicitly into account. In their recent idea and perspective paper in Ecology Letters, Rybicki and Hanski (2013) remedied this deficiency by extending the power-law species area relationship model with an additional term that accounts for the fragmentation effect on the number of surviving species. Applying the extended model in multi species simulations, they reach an important conclusion: when the total amount of remaining habitat is small $(<15-20 \%$ of the original area in the example they provided), a high degree of fragmentation is highly detrimental to long-term persistence of species.

The findings of Rybicki and Hanski (2013) are not only scientifically interesting, but they also have important implications for practical conservation; Based on their results, Rybicki and Hanski (2013) recommend that habitat fragments should be protected in clusters rather than as randomly scattered fragments. They also reiterate the third-ofthird rule-of-thumb suggested earlier by Hanski (2011), according to which the habitat fragments to be protected should be clustered on one third of the total landscape, within which one-third of the area should be covered by the actual protected habitat fragments.

We commend these ideas and trust they will have farreaching practical consequences on our future land use planning and conservation prioritization. However, exactly because of this trust, we wish to point out that when practitioners start to employ the clustering idea, they should be conscious that this choice of action implicitly embraces habitat conservation triage.

Conservation triage is a controversial issue the proponents of which argue that it is simply an unavoidable step in the process of prioritizing the allocation of limited conservation resources, and as 
such should not be confused with taking ethical positions (Bottrill et al. 2008). Indeed, we agree that for the overarching goal of conservation (ensuring the long term persistence of species and ecosystem functioning) to ever succeed, it is vital that decision makers and conservation practitioners explicitly acknowledge that there are always tradeoffs resulting from investing in one conservation action over another, i.e. they should be consciously aware of the constant triage nature of conservation decision making (Bottrill et al. 2008, 2009). A good example of a conservation triage is the debate about whether allocating resources to the most endangered species will ultimately lead to preservation of the greatest number of species or whether this goal can be better achieved by giving priority to cost-effective actions and admit that we may lose some of the most endangered species while saving the majority of the others (Pimm 2000; Wilson et al. 2011; Schoemaker et al. 2013).

We think that Rybicki and Hanski's (2013) principle of clustering (which is not meant to be applied blindly) remains an important message for conservation simply because clustering evidently allows more species to persist in the landscape. Indeed, the point of this comment is not to criticize Rybicki and Hanski (2013), but merely to point out that while clustering appears to be a sensible conservation action, in the world of competing interests and limited resources we must be explicitly aware that every sensible thing we do is another sensible thing we do not (Gilbert 2011, Game et al. 2013). Clustering the habitat fragments seems like an easy answer to our conservation problem only because it describes what we will do without describing simultaneously what we will not. Thus, if we make it a priority to cluster all new protected habitat fragments into one third of the landscape, we need to understand that we simultaneously make a decision to write off the further protection of two thirds of the landscape.

\section{References}

Bottrill, M. C., Joseph, L. N., Carwardine, J., Bode, M., Cook, C., Game, E. T., Grantham, H., Kark, S., Linke, S., McDonald-Madden, E., Pressey, R. L., Walker, S., Wilson, K. A. \& Possingham, H. P.
(2008). Is conservation triage just smart decision making? Trends Ecol. Evol., 23, 649-654. http://dx.doi.org/10.1016/ j.tree.2008.07.007

Bottrill, M. C., Joseph, L. N., Carwardine, J., Bode, M., Cook, C., Game, E. T., Grantham, H., Kark, S., Linke, S., McDonald-Madden, E., Pressey, R. L., Walker, S., Wilson, K. A. \& Possingham, H. P. (2009). Finite conservation funds mean triage is unavoidable. Trends Ecol. Evol., 24, 183-184. http://dx.doi.org/10.1016/ j.tree.2008.11.007

Fahrig, L. (2003). Effects of habitat fragmentation on biodiversity. Annu. Rev.Ecol. Evol. Syst., 34, 487-515. http://dx.doi.org/10.1146/ annurev.ecolsys.34.011802.132419

Game, E.T., Kareiva, P. \& Possingham, H.P. (2013). Six Common Mistakes in Conservation Priority Setting. Conservation Biology 27: 480-485. http://dx.doi.org/10.1111/cobi.12051.

Gilbert, D. (2011). Buried by bad decisions. Nature, 474, 275-277. http://dx.doi.org/10.1038/474275a

Hanski, I. (2005). The Shrinking World: Ecological Consequences of Habitat Loss. International Ecology Institute, Oldendorf/Luhe.

Hanski, I. (2011). Habitat loss, the dynamics of biodiversity, and a perspective on conservation. Ambio, 40, 248-255. http://dx.doi.org/10.1007/ s13280-011-0147-3

He, F.L. \& Hubbell, S.P. (2011). Species-area relationships always overestimate extinction rates from habitat loss. Nature, 473, 368-371. http://dx.doi.org/10.1038/nature09985

Lomolino, M.V. (2000). Ecology's most general, yet protean pattern: the species area relationship. J. Biogeogr., 27, 17-26. http://dx.doi.org/10.1046/ j.1365-2699.2000.00377.x

Pimm, S.L. (2000). Against triage. Science, 289, 2289.

http://dx.doi.org/10.1126/ science.289.5488.2289

Rosenzweig, M. L. (1995). Species diversity in space and time. Cambridge University Press, Cambridge.

Rybicki, J. \& Hanski, I. (2013). Species-area relationships and extinctions caused by habitat loss and fragmentation. Ecol. Lett., http://dx.doi.org/10.1111/ele.12065.

Shoemaker, K.T., Breisch, A.R., Jaycox, J.W. and Gibbs, J.P. (2013). Reexamining the Minimum Viable Population Concept for Long-Lived Species. Conservation Biology. http://dx.doi.org/ 10.1111/cobi.12028 
Wilson, H.B., Joseph, L.N., Moore, A.L. \& Possingham, H.P. (2011). When should we save the most endangered species? Ecol. Lett., 14, 886-890. j.1461-0248.2011.01652.x

Funding: No specific funding is attributed for this work

Competing interests: Authors declare no competing interests exist

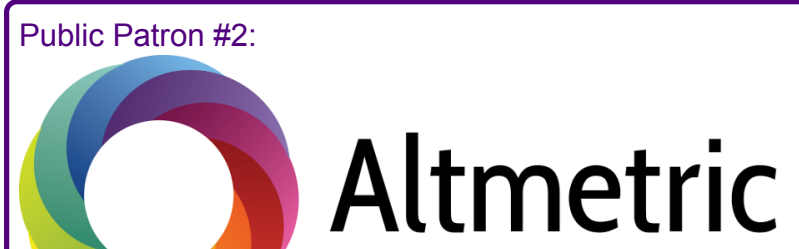

Public Patron \#3:

Anonymous patron 